\title{
Effect of Aspartame on Acetylcholinesterase Activity in Some of Rat Tissues
}

\section{Aspartamın Sıçanların Beyin, Karaciğer, Böbrek ve Akciğer Dokularında Asetilkolinesteraz Aktivitesi Üzerine Etkisi}

Research Article

Fikriye Polat ${ }^{*}$, Egemen Dere ${ }^{2}$, Ferda Arı ${ }^{2}$, Nesrin Turaçlar ${ }^{3}$, Günsel Bingöl ${ }^{4}$, Nazlıhan Aztopal ${ }^{2}$

'Department of Primary Education, Faculty of Education, Kocaeli University, Kocaeli, Turkey.

2Department of Biology, Faculty of Science and Letter, Uludağ University, Bursa, Turkey.

${ }^{3}$ Vocational School of Health Services, Selçuk University, Konya, Turkey.

${ }^{4}$ Department of Biomedical Engineering, Faculty of Engineering and Natural Sciences, Yıldırım Beyazıt University, Ankara, Turkey.

\section{ABSTRACT}

\begin{abstract}
$\mathrm{n}$ this study, the changes in acetylcholinesterase (AChE) activity in the liver, lungs, kidney and brain tissues were investigated in the rats administered aspartame intraperitoneally. Aspartame, a widely used artificial sweetener, was given to the rats at doses of 50,100 and $200 \mathrm{mg} / \mathrm{kg}$. Changes in enzyme activity were recorded at 12 and $24 \mathrm{~h}$ following the injection. The activities of AChE at $12 \mathrm{~h}$ for all doses were significantly higher in the liver and kidney but not in those of lung and brain. However, the activities in the liver and kidney at $24 \mathrm{~h}$ after treatment for $200 \mathrm{mg} / \mathrm{kg}$ were similar to that of control. Consequently, it was observed that aspartame caused increases in the activities of AChE in the liver and kidney during the first hours after treatment but lost its effect at later times.
\end{abstract}

\section{Key Words}

Acetylcholinesterase, aspartame, enzyme, activity, rat.

\section{Ö Z}

Q çalışmada, sıçanlara intraperional verilen aspartamın, karaciğer, akciğer, böbrek ve beyin dokularında basetilkolinesteraz (AChE) aktivitesindeki değişiklikler araştırıldı. Yapay tatlandırıcı olarak yaygın bir şekilde kullanılan aspartam, erkek Wistar sıçanlara $(n=36) 50,100$ ve 200 mg/kg olarak verildi. Enjeksiyonu takiben 12 ve 24 saat sonra enzim aktivitesindeki değişiklikler kaydedildi. 12 saatteki bütün dozlarda AChE aktiviteleri karaciğer ve böbrekte önemli bir şekilde daha yüksekti. Fakat akciğer ve beyinde aynı yüksek değerler gözlenmedi. Buna rağmen, 200 mg/kg uygulamasından 24 saat sonra karaciğer ve böbrekteki aktiviteler kontrolünkiyle benzerdi. Sonuç olarak, sıçanın farklı dokularında aspartamın AChE enzim aktivitelerinde bazı değişiklere neden olduğu bulundu. AChE enzim aktivitelerindeki değişikliklerin nedenleri bu çalışmada tartışıldı.

\section{Anahtar Kelimeler}

Asetilkolinesteraz, aspartam, enzim aktivitesi, sıçan.

Article History: Received: Apr 20, 2017; Revised: Jul 20, 2017; Accepted: Oct 25, 2017; Available Online: Dec 25, 2017.

DOI: 10.15671/HJBC.2017.172

Correspondence to: F. Polat, Department of Primary Education, Faculty of Education, Kocaeli University, Kocaeli, Turkey. 


\section{INTRODUCTION}

Compounds added to our foods to make them sweet are called as sweeteners. They are divided into two groups as natural and artificial [1]. Artificial sweeteners, about 200-300 times sweeter than sugar, are used to flavor foods due to the prohibition of natural sweeteners specifically for diabetics. Besides aspartame, there are various artificial sweeteners without energy such as aspartame, acesulfame- $\mathrm{K}$, saccharin and cyclamate. Cyclamate is 45 times as sweet as sugar, aspartame, saccharin, sucralose are 180, 300 and 600 times as sweet, respectively, and neotame known as a type of aspartame is 13000 times sweeter [2].

Aspartame is a methyl ester of dipeptide of aspartic acid and phenylalanine. It is digested by esterases and peptidases [3]. Aspartame and its metabolites were allowed to be used as artificial sweetener after they were found not to be carcinogenic, toxic, mutagenic and teratogenic [4]. However, many scientists are suspicious of aspartame consumption, because of concerning about neurotoxicity of aspartame, effects of phenylalanine on brain function and toxic effect of methanol metabolite [5]. In a study, it was shown that intoxication of methanol was related with mitochondrial damage and increased oxygen radicals [6]. It was suggested that excess of formaldehyde formed during by acute methanol intoxication caused significant increases in lipid peroxidation by Parthasarathy et al. [7]. In another study, it was reported that activity of Cytochrome p450 enzyme was increased in brain of rats treated with aspartame at daily doses of 75 and $125 \mathrm{mg} / \mathrm{kg}$ for 30 days [8]. The study conducted by Iman showed that aspartame increased oxidative stress in liver and kidney tissues of male rats by examining the changes in the levels of GSH and the activities of superoxide dismutase (SOD), glutathione-Stransferase (GST) and catalase (CAT) [9]. Another study on the chronic effect of aspartame showed that it increased lipid peroxidation (LPO) and also increased SOD, glutathione peroxidase (GPX) and CATactivity were but decreased GSH level and protein thiol [10]. The other study on the role of antioxidant enzymes in oxidative stress and immune response evaluation of aspartame in blood cells of Wistar albino rats showed that there were significant and time-dependent decreases in the activities of Na/K-ATPase, Ca-ATPase and Mg-ATPase localized in red blood cell membranes treated with aspartame for 15, 30 and 90 days. Furthermore, it was reported that there were significant increases in lipid peroxidation, free radical production and the activities of SOD, CAT and GPx, and there were also increases in the levels of nonenzymatic antioxidants (GSH and $C$ vitamin) [11]. The microscopic study on brains of newborns following administration of aspartame to pregnant rats showed that there were decreases in the size of both neurons and nucleus of neurons. Furthermore, there were nuclear pyknosis, swellings of the mitochondria and endoplasmic reticulum, degeneration of myelin sheath and extensive vacuole formation of cytoplasm and axoplasm [12]. It was also pointed out that the dose of $1000 \mathrm{mg} / \mathrm{kg} / \mathrm{day}$ of aspartame significantly increased plasma alanine aminotransferase (ALT), aspartate aminotransferase (AST), alkalen fosfatase (ALP) and $\gamma$-glutamyl transpeptidase $(\gamma \mathrm{GT})$ levels in animals [13].

AChE (E.C.3.1.7) is an enzyme released from the nerve endings and neuromuscular junction. There are two forms of the enzyme known as acetylcholinesterase and pseudocolinesterase [14].

AChE, which catalyzes the reaction of acethyl and choline from acetylcholine playing role in transporting of impulse at neurons, is widely used as an indicator todetect the neurotoxic effect [15]. In the study on the effect of dichlorvos, an organophosphate insecticide, in the activity of AChE enzyme in rat serum, brain, liver, kidney and small intestine tissues, it was suggested that there were significant decreases in enzyme activities [16]. In the research of Tsakiris and co-workers, studying the effects of aspartame on acethycholinesterase activity in human erythrocyte membrane, it was reported that aspartame doses of 34,150 and $200 \mathrm{mg} / \mathrm{kg}$ decreased the enzyme activity by $33 \%, 41 \%$, and $57 \%$ respectively [17]. Also, in another study searching the effect of aspartame metabolites on the AChE activity in frontal cortex of rats, 
aspartame inhibited the enzyme activity at the rate between $11 \%$ and $29 \%$. Furthermore, these reductions were indicated to be at the $p<0,0001$ significance level [18]. In another study by the same research group, aspartame metabolites were shown to inhibit rat hippocampal AChE activity [19].

Although cancerogenic character of aspartame is known, has been discussed in many studies, we want to do this research, as it is interesting that aspartame has still used in many diet foods. In the present study, we aimed to investigate the changes in the activities of AChE in liver, kidney, lung and brain tissues in rats at 12 and $24 \mathrm{~h}$ following the aspartame administration.

\section{MATERIALS and METHODS}

\section{Animals}

Healthy adult male and female Wistar albino rats, 8-10 weeks of age, with an average body weight of 180-200 g, were used in this study. The rats were obtained from the Experimental Medical Research Unit at Kocaeli University, Turkey. The rats were randomly selected and housed in polycarbonate cages with free access to tap water and rat chow with a $12 \mathrm{~h}$ dark/light cycle. The temperature value of the animal laboratory was $22 \pm 2^{\circ} \mathrm{C}$ and the relative humidity was $50-70 \%$. For each dose group, four animals were used and were allowed one week to adjust to their new environment. All procedures on animals were performed in accordance with the guidelines of the Animal Ethics Committee of the Kocaeli University School of Medicine (Kou Hadyek 1/2-2012)

\section{Experimental Design and Doses}

In this study, the food preservative Aspartame (CAT No: A5139) was used as the test substance. 8-10 week old male Wistar albino rats, weighing 180-200 g were used for the experiment. The rats were divided into 7 different groups of 6 animals each. Six were treatment groups and one was control group. Aspartame was dissolved in distilled water. The rats were administered a single dose of aspartame intraperitoneally at concentrations of 50,100, and $200 \mathrm{mg} / \mathrm{kg}$ b.w. for 12 and $24 \mathrm{~h}$ before sacrifice. The distilled water administered control group was referred to the solvent control. The rats were sacrificed by cervical dislocation after aspartame treatment and the necessary studies were commenced.

\section{Extraction of Tissues}

Liver, lung, kidney and brain tissues were rapidly removed from sacrificed rats and rinsed with ice-cold $0.15 \mathrm{M} \mathrm{KCl}$. After wiped with a tissue paper, tissues were weighed on a microbalance. Tissues were transferred into 3 volumes $(\mathrm{w} / \mathrm{v})$ of ice-cold $0.15 \mathrm{KCl}(0.5 \mathrm{~g}$ tissue into $1.5 \mathrm{~mL})$ and homogenized at $1500 \mathrm{r} / \mathrm{min}$ stirring speed with 4 pulse time on T-line laboratory stirrer-type homogenizer (model No: 136-2). Eve homogenate was centrifuged at $48000 x g$ for 30 minutes in Sorval RC-5 super speed refrigerated centrifuge (Dupont Instruments). It was paid attention that processes of homogenization and centrifugation were carried out at $+4^{\circ} \mathrm{C}$. Enzyme activities in fresh supernatants were detected using Boehringer Mannheim method [20]. Bradford assay was used for protein analysis and bovine serum albumin was used for protein standard [21].

\section{Statistical Analysis}

The collected data were analyzed using the statistical program SPSS 13.O. Data for the control and experiment groups were evaluated using $t$ test. The mean values were determined with ANOVA test. Probability $p<0.05$ was considered to be significant. Pearson correlation test was used to evaluate relationships between variables [22].

\section{RESULTS and DISCUSSIONS}

The present study showed the effect of intraperitoneally administration of 50,100 and $200 \mathrm{mg} / \mathrm{kg}$ of aspartame on liver, kidney, lung and brain of Wistar albino rats at different two time periods. Time-dependent alterations of AChE activities in the tissues are presented in Table 1. Among control and experimental groups, no differences were observed in the activities of AChE in the lung and brain tissues.

The activity of AChE in the liver was significantly increased after $12 \mathrm{~h}$ of aspartame treatment for all doses (50, 100, $200 \mathrm{mg} / \mathrm{kg}$ ) when compared to the control group. Statistically significant increases were observed after $24 \mathrm{~h}$ of 
Table 1. Changes in AChE activity following exposure to aspartame in rat liver, kidney, lung and brain, in relation to time.

\begin{tabular}{|c|c|c|c|c|c|c|c|c|c|}
\hline \multirow[b]{2}{*}{ Enzyme } & \multirow[b]{2}{*}{$\begin{array}{c}\text { Doses / } \\
\text { Hour }\end{array}$} & \multicolumn{2}{|c|}{ Liver } & \multicolumn{2}{|c|}{ Kidney } & \multicolumn{2}{|c|}{ Lung } & \multicolumn{2}{|c|}{ Brain } \\
\hline & & $\begin{array}{c}12 \mathrm{~h} \\
\text { Mean } \pm \text { SE }\end{array}$ & $\begin{array}{c}24 \mathrm{~h} \\
\text { Mean } \pm \text { SE }\end{array}$ & $\begin{array}{c}12 \mathrm{~h} \\
\text { Mean } \pm \text { SE }\end{array}$ & $\begin{array}{c}24 \mathrm{~h} \\
\text { Mean } \pm \text { SE }\end{array}$ & $\begin{array}{c}12 \mathrm{~h} \\
\text { Mean } \pm \text { SE }\end{array}$ & $\begin{array}{c}24 \mathrm{~h} \\
\text { Mean } \pm \text { SE }\end{array}$ & $\begin{array}{c}12 \mathrm{~h} \\
\text { Mean } \pm \text { SE }\end{array}$ & $\begin{array}{c}24 \mathrm{~h} \\
\text { Mean } \pm \text { SE }\end{array}$ \\
\hline \multirow{4}{*}{ AChE } & Control & $0.071 \pm 0.01^{*}$ & $\begin{array}{c}0.096 \\
\pm 0.02 *\end{array}$ & $0.047 \pm 0.01 *$ & $0.072 \pm 0.02 *$ & $0.056 \pm 0.01 *$ & $0.064 \pm 0.01 *$ & $0.046 \pm 0.01 *$ & $0.049 \pm 0.02 *$ \\
\hline & $50 \mathrm{mg}$ & $0.117 \pm 0.02 \dagger$ & $0.120 \pm 0.01 \dagger$ & $0.074 \pm 0.02 \dagger$ & $0.092 \pm 0.02 \dagger$ & $0.076 \pm 0.06 *$ & $0.067 \pm 0.01 *$ & $0.036 \pm 0.01 *$ & $0.036 \pm 0.01 *$ \\
\hline & $100 \mathrm{mg}$ & $0.104 \pm 0.03 \dagger$ & $0.131 \pm 0.03+$ & $0.066 \pm 0.01 \dagger$ & $0.077 \pm 0.02 *$ & $0.057 \pm 0.03^{*}$ & $0.069 \pm 0.02 *$ & $0.036 \pm 0.02 *$ & $0.040 \pm 0.01 *$ \\
\hline & $200 \mathrm{mg}$ & $0.113 \pm 0.02 \dagger$ & $0.102 \pm 0.01 *$ & $0.064 \pm 0.01 \dagger$ & $0.074 \pm 0.02 *$ & $0.069 \pm 0.04 *$ & $0.069 \pm 0.01^{*}$ & $0.044 \pm 0.00 *$ & $0.043 \pm 0.00 *$ \\
\hline
\end{tabular}
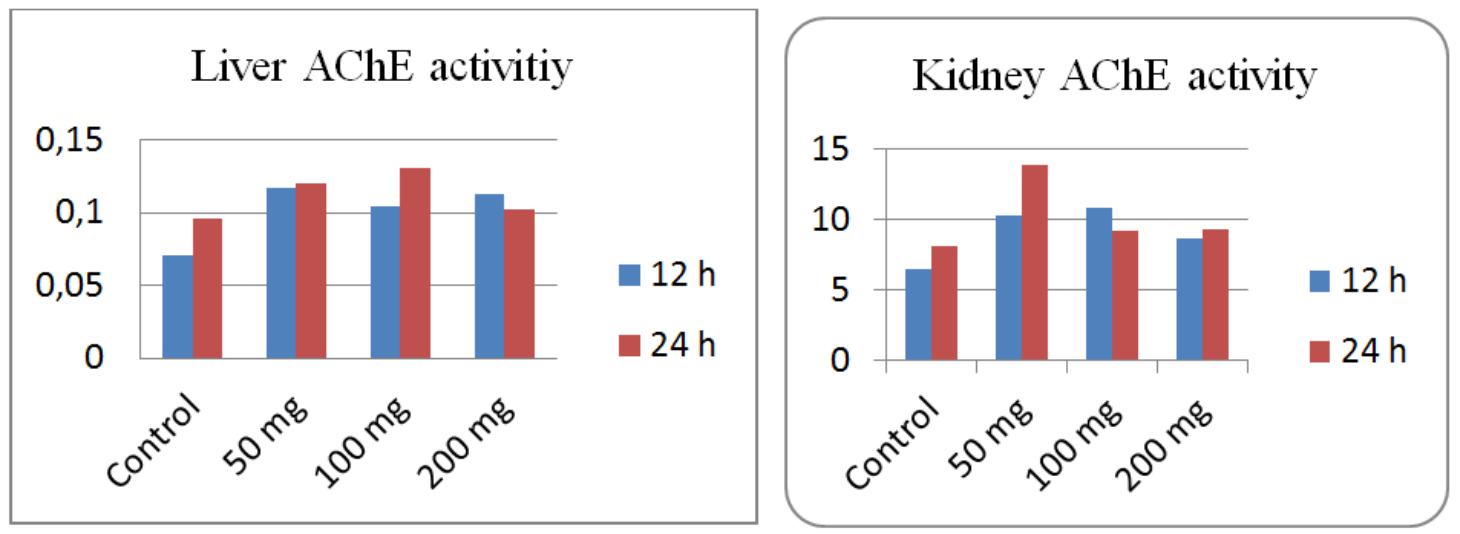

Figure 1. Effect of aspartame on AChE activity in liver and kidney tissues.

aspartame treatment at doses of 50 and $100 \mathrm{mg} /$ $\mathrm{kg}$, but no differences were observed at the dose of $200 \mathrm{mg} / \mathrm{kg}$ (Figure 1).

The activity of AChE in the kidney was significantly increased after $12 \mathrm{~h}$ of aspartame treatment for all doses $(50,100,200 \mathrm{mg} / \mathrm{kg}$ ) when compared to the control group. There was statistically significant increase after $24 \mathrm{~h}$ of treatment for the dose of $50 \mathrm{mg} / \mathrm{kg}$, but the activities observed in groups treated with 100 and $200 \mathrm{mg} / \mathrm{kg}$ doses were similar to that of control group (Figure 1).

\section{DISCUSSION}

Aspartame, an artificial sweetener, is mostly used in many dry beverages, cakes, puddings, chewing gum, breakfast cereals and drink beverages $[18,19,23]$. It is immediately hydrolyzed in the gastric lumen metabolizing phenylalanine, aspartic acid and methanol. Following aspartame consumption, concentrations of its metabolites are increased in the blood stream [17-19].
Phenylalanine is converted to tyrosine and very little to phenethylalanine; Aspartic acid is converted to alanine and oxaloacetic acid. Methanol is also converted to formaldehyde and then to formic acid. Toxicity of aspartame is generally related to formation of methanol and formaldehyde.

Free methanol is created when aspartame is heated to above $30^{\circ} \mathrm{C}$. This also happens when a product, for example a food, containing aspartame is heated. The methanol produced during chemical digestion of aspartame is gradationally secreted into the small intestine and broken down into formic acid and formaldehyde. Formaldehyde is a deadly neurotoxin [10].

Studies on aspartame toxicity have contradictory results. Some studies using in vivo and in vitro tests have shown that aspartame doesn't cause genotoxicity, DNA damaging and mutagenesis, but it stimulates chromosome aberrations and micronucleus formation $[23,24]$. One of the studies has reported that 
aspartame causes DNA strand breaks in bone marrow, whereas other one has indicated that it is not potentially mutagen using Ames test and it doesn't stimulate cancer at even high doses. Regarding to studies in humans, aspartame has been found to be safe, but it may be harmful resulting in formaldehyde accumulation $[25,26]$. Alleva et al. reported that aspartame was an angiogenic agent and caused formation of new blood vessel walls [27].

AChE hydrolyzes acetylcholine into its inactive components; choline and acetic acid. AChE inhibition increases acetylcholine both at neuron synapses and neuromuscular junctions and therefore it causes excessive stimulation of acetylcholine receptors. This is followed by paralysis of cholinergic synaptic at central nervous system, autonomic ganglia, sympathetic and parasympathetic nerve endings and somatic neurons. Central and peripheral clinic symptoms also occur, due to cholinergic paralysis. Accumulation of acetylcholine at neuromuscular junction causes nicotinic effects including muscle weakness, hypertension and tachycardia, similarly, muscarinic effects at smooth muscle occurs thus affecting several organs which include lung, gastrointestinal, eye, bladder and secretory gland $[28,29]$.

Although there are numerous publications found in the literature on the inhibition of AChE activity, there are only few studies on the increased AChE activation. In studies conducted by Büyükbaş et al. and Yao, slightly and mildly increased AChE activity was observed in patients having obesity, diabetes mellitus, hiperlipemia, nodular goiter, psoriasis, essential hypertension, thyrotoxicosis, nephrosis, asthma, alcoholism, anxiety and schizophrenia [30,31]. In addition, Yao reported that succinylcholine was rapidly inactivated in a patient with pseudocholinesterase hyperactivity, and also indicated that most of the genetic variants of pseudocholinesterase were related to decreased activity of the enzyme. However, few variants are prominently related to increased activity of AChE rather than decreased activity of it. In a study, $\mathrm{C} 5+$, a variant for $\mathrm{AChE}$, has been detected as an isoenzyme electrophoretic due to working 30\% more than normal enzyme activity [31,32].
In the present study, the activity of AChE in the liver tissue was significantly increased after 12 $\mathrm{h}$ of aspartame treatment. Although statistically significant increases were observed after $24 \mathrm{~h}$ of treatment at the doses of 50 and $100 \mathrm{mg} / \mathrm{kg}$, values at the dose of $200 \mathrm{mg} / \mathrm{kg}$ were similar that of control (Figure 1). Studies on organophosphates have indicated that the active center of AChE enzyme is phosphorylated, thus leading to the active center to be filled. Then the loss of AChE activity causes accumulation of choline at synaptic gaps and results in muscle paralyze, attack and death. Some compounds used for the treatment of organophosphate poisonings reactivate cholinesterase by scavenging phosphoril groups. Reactivation of "aged enzyme", which is a form of an enzyme, is not possible, but the activity of aged plasma enzyme only returns to normal in vivo by synthesis of new enzyme in liver [28].

In our study, the doses of 50, 100 and 200 $\mathrm{mg} / \mathrm{kg}$ of aspartame caused significant increases in the activity of AChE in the kidney at $12 \mathrm{~h}$, but only the dose of $50 \mathrm{mg} / \mathrm{kg}$ caused significant increases at $24 \mathrm{~h}$ and the other doses remained similar to that of control (Figure 1). The study on rats treated with radio labeled aspartame showed that formaldehyde derived from aspartame accumulated in the brain, liver, kidney and other tissues by binding to protein and DNA after ingestion of either 20 or $200 \mathrm{mg} / \mathrm{kg}$ of aspartame [33].

From studies, it has been known that aspartame is metabolized following ingestion [17-19]. Aspartic acid, a metabolite of aspartame, is an excitatory amino acid and exists in high level in brain. These levels are controlled by the blood-brain barrier, which protects the brain from fluctuations created by plasma aspartate. In the present study, in the brain of Wistar albino rats, aspartame at the all doses and time periods did not cause any differences in the activity of AChE, and this result was probably related to blood-brain barrier. However, In the study on determination of oxidative stress in rat cerebral cortex, Mourad and Noor showed that treatment for 4 and 6 weeks decreased level of GSH and increased activities of superoxide dismutase (SOD), glutathioneS-transferase (GST) and catalase (CAT) after 
administration of $40 \mathrm{mg} / \mathrm{kg}$ of aspartame at the periods of 2, 4 and 6 weeks. Regarding this research group, it has been assumed that longterm ingestion of aspartame may stimulate oxidative stress in rat cerebral cortex [34].

In some studies, blood $\mathrm{MeOH}$ concentration even after ingestion of large doses of aspartame is lower than the studies reported using directly $\mathrm{MeOH}$ toxication. $\mathrm{MeOH}$ is completely absorbed and may interact with cell membrane lipids in rat cortex and/or AChE enzyme in rat frontal cortex, and this may cause a decrease in enzyme activity. Primer metabolic effect of methanol is its oxidation into formaldehyde and then into formate. The toxic effect of methanol in humans results from the accumulation of format, which is an oxidation product of methanol $[10,18]$.

Phenylalanine is essential amino acid required in the production of monoamines and exists in almost all food with protein. Despite this, high level of phenylalanine in blood formed after aspartame consumption may cause damage in the brain [10]. Thus some studies have showed that levels of some amino acids in brain are increased after aspartame consumption [35-37]. In our study, although aspartame, even at high doses, has not caused any differences in the activity of AChE in the brain tissue, we assume that increased level of phenylalanine, a metabolic product of aspartame, will occur detrimentallyin genetic metabolic diseases such as phenylketonuria (PKU). In $\mathrm{PKU}$, phenylalanine is abnormally converted to toxic phenylpyruvic acid due to the lack of phenylalanine hydroxylase enzyme. Accumulation of phenylpyruvic acid causes mental retardation in child [10]. The high plasma concentration of phenylalanine causes increases the entry of other neutral amino acids into brain. Consequently, the high plasma levels of phenylalanine increase levels of dopamine and norepinephrine, and then affect brain functions [34].

As a result, in the present study, the effect of aspartame on the AChE activity was examined in rat liver, kidney, lung and brain tissues and the increased enzyme activities in liver and kidney tissues were observed at the first hours following treatments.

\section{ACKNOWLEDGEMENTS}

We would like to thank to Scientific Research Project Unit of Kocaeli University (Project number: 2012-14-HDP).

\section{References}

1. I. Saldamlı, Gıda Katkı Maddeleri ve Ingrediyenler, HÜ Gıda Müh. BI., Ankara, (1985) 120-121.

2. American Dietetic Association. Position of the American Dietetic Association, Use of nutritive and nonnutritive sweeteners, J. Am. Diet. Assoc., 10 (2004) 255-275.

3. Ş.G. Öz, Aspartam: Güvenilirliği üzerine yapılan tartışma, Ankara Üni. Tıp Fak. Mecmuası., 56 (2003) 113-120.

4. L. Fix, J.L. Allen, Summary of the symposium establishing the safety of fat and macronutrient substitutes presented at the 33rd Annual Meeting of the Society of Toxicology, San Diego, California, March 13-17, (1994), Regul. Toxicol. Pharmacol., 27 (1998) 200-203.

5. H.H. Butchko, W.W. Stargel, Aspartame: Scientific evaluation in the postmarketing period, Regul. Toxicol. Pharmacol., 34 (2001) 221-233.

6. G.D. Castro, M.H. Costantini, A.M. Delgado de layno, A. Castro, Rat liver microsomal and nuclear activation of methanol to hydroxyl methyl free radicals, Toxicol. Lett., 129 (2002) 227- 236.

7. J.N. Parthasarathy, S.K. Ramasundaram, M. Sundaramahalingam, S.D. Pathinasamy, Methanol induced oxidative stress in rat lymphoid organs, J. Occup. Health., 48 (2006) 20-27.

8. A. Vences-Mejia, N. Labra-Ruiz, N. HernandezMartinez, V. Dorado-Gonzales, J. Gomez-Garduno, I. Perez-Lopez, R. Nosti-Palacios, R. Camocho-Carranza, J.J. Espinosa-Aguirre, The effect of aspartame on rat brain xenobiotic-metabolizing enzymes, Human Exp. Toxicol., 25 (2006) 453-459.

9. M.M. Iman, Effect of aspartame on some oxidative stres parameters in liver and kidney of rats, Afr. J. Pharm. Pharmacol., 5 (2011) 678-682.

10. A. Iyyaswamy, S. Rathinasamy, Effect of chronic exposure to aspartame on oxidative stress in the brain of albino rats, J. Biosci., 37 (2012) 679-688.

11. K.C. Arbind, D.R. Sheela, L. Sundareswaran, Role of antioxidant enzymes in oxidative stress and immune response evaluation of aspartame in blood cells of Wistar albino rats, Int. Food Res. J., 21 (2014) 22632272.

12. C. Puicâ, C. Crâciun, M. Borsa, M. Rusu, I. Roman, M. Cristescu, Protective effects of a biactive antioxidant complex against aspartame exposure during gestation biochemical morphological and ultra structurel studies on new-born rat brain, Life Scien., 18 (2008) 195-208.

13. L. Stanley, Review of data on the food additive aspartame, Supporting Publications, European Food Safety Authority, 399 (2013) 45-50.

14. A. Sarıtaş, Z. Çakır, Ş. Aslan, Organofosfat ve karbamat zehirlenmeleri, The Eurasian J. Med., 39 (2007) 55-59. 
15. S.M. Moreira, L. Guilhermino, The use of mytilus galloprivincialis acetylcholinesterase and glutathione s-transferases activities as biomarkers of environmental contamination along the northwest Portguese coast, Environ. Monitoring Assessment. 105 (2005) 309-325.

16. E. Dere, F. Arı, S. Uğur, The effect of dichlorvos on acetylcholinesterase activity in some tissues in rats, Acta Vet. (Beograd)., 60 (2010) 123-131.

17. S. Tsakiris, A. Giannoulia-Karantana, I. Simintzi, K.H. Schulpis, The effect of aspartame metabolites on human erythrocyte membrane acetylcholinesterase activity, Pharmaco. Res., 53 (2006) 1-5.

18. I. Simintzi, K.H. Schulpis, P. Angelogianni, C, Liapi, S. Tsakiris, The effect of aspartame metabolites on the suckling rat frontal cortex acetylcholinesterase, An in vitro study, Food Chem. Toxicol., 45 (2007) 2397 2401.

19. I. Simintzi, K.H. Schulpis, P. Angelogianni, C. Liapi, S. Tsakiris, The effect of aspartame on acetylcholinesterase activity in hippocampal homogenates of suckling rats, Phamacol. Res., 56 (2007b) 155-159.

20. G. Bohringer Manheim, Acetylcholinesterase; in Biochemica information, I (1973) 11.

21. M.M. Bradford, A rapid and sensitive for the quantitation of microgram quantitites of protein utilizing the principle of protein-dye binding, Anal. Biochem., 72 (1976) 248-254.

22. H.Z. Jerrold, Biostatistical Analysis prentice-Hall Inc, Englewood Cliffs, New Jersey, (1984) 138-178.

23. E. Rencuzoğullari, B.A. Tüylü, M. Topaktaş, H.B. Ila, A. Kayraldız, M. Arslan, S.Budak Diler, Genotoxicity of aspartame, Drug Chem. Toxicol., 27 (2004) 257-268.

24. A.M. Jeffrey, G.M. Williams, Lack of DNA-damaging activity of five nonnutritive sweeteners in the rat hepatocyte/DNA repair assay, Food Chem. Toxicol. 38 (2000) 335-338.

25. C. Trocho, R. Pardo, I. Rafecas, J. Virgili, X. Remesar, J.A. Fernandez-Lopez, M. Alemany, Formaldehyde derived from dietary aspartame binds to tissue components in vivo, Life Sci., 63 (1998) 337-349.

26. T.R. Tephly, Comments on the purported generation of formaldehyde and adduct formation from the sweetener aspartame, Life Sci., 65 (1999) 157-160.
27. R. Alleva, B. Borghi, L. Santarelli, E. Strafella, D. Carbonari, M. Bracci, M. Tomasetti, In vitro effect of aspartame in angiogenesis induction, Toxicology in Vitro., 25 (2011) 286-293.

28. T.T. Küçükkılınç, Organofosfat zehirlenmelerinde asetilkolinesterazın biyotemizleyici olarak kullanılma olasılığı, Turk J. Biochem., 39 (2014) 126-131.

29. M. Yılmaz, A. Sebe, M.O. Ay, M. Gürger, Organofosfat Zehirlenmesi ve Intermediate Sendromu, Arşiv Kaynak Tarama Dergisi., 25 (2016) 70-83.

30. S. Büyükbaş, H. Atalay, A. İnal, K. Başaralı, Tip II diyabetiklerde kronik hipergliseminin askorbat ve kolinesteraz düzeylerine etkisi, Tıp Araştırmaları Dergisi. 6 (2008) 1-6.

31. F.S.F. Yao, J.J. Savarese, Pseudocholinesterase Hyperactivity with Succinylcholine Resistance: An Usual Cause of Difficult Intubation, J. Clin. Anesth., 9 (1997) 328-330.

32. H. Harris, D.A. Hopkinson, E.B. Robson, M. Whittaker, Genetical studies on a new variant of serum cholinesterase detected by electrophoresis, Ann. Hum. Genet., 26 (1963) 359-382.

33. C. Troche, R. Pardo, I. Rafecas, J. Virgili, X. Remesar, J.A. Fernandez-Lopez, M. Alemany, Formaldehyde derived from dietary aspartame binds to tissue components, Life Sciences., 13 (1998) 337-349.

34. I.M. Mourad, N.A. Noor, Aspartame (a widely used artificial sweetener) and oxidative stres in the rat cerebral cortex, Int. J. Pharm. Biomed. Sci., 2 (2011) 4-10.

35. J.W. Dailey, S.M. Lasley, R.L. Burger, A.F. Bettendorf, P.K. Mishra, P.C. Jobe, Amino acids, monoamines and audiogenic seizures in genetically epilepsy-prone rats: effects of aspartame, Epilepsy Res., 8 (1991) 122-133.

36. L. Diomede, M. Romano, G. Guiso, S. Caccia, S. Nava, M. Salmona, Interspecies and interstrain studies on the increased susceptibility to metrazol-induced convulsions in animals given aspartame, Food Chem. Toxicol., 29 (1991) 101-106.

37. H. Yokogoshi, C.H. Roberts, B. Caballero, R.J. Wurtman, Effects of aspartame and glucose administration on brain and plasma levels of large neutral amino acids and brain 5-hydroxyindoles, Am. J. Clin. Nutr., 40 (1984) 1-7. 
